\title{
Selected Adipokines - Plasma Concentrations and Adipose Tissue Expressions during 24-Hour Lipid Infusion in Healthy Men
}

\author{
J. KOPECKÝ, Jr ${ }^{1}$, E. KRUŠINOVÁ ${ }^{1}$, M. KLEMENTOVÁ ${ }^{\mathbf{1}}$, L. KAZDOVÁ ${ }^{\mathbf{1}}$, \\ P. MLEJNEK ${ }^{2}$, M. PRAVENEC ${ }^{2}$, M. HILL ${ }^{3}$, T. PELIKÁNOVÁ ${ }^{1}$ \\ ${ }^{1}$ Diabetes Center, Institute for Clinical and Experimental Medicine, Prague, Czech Republic, \\ ${ }^{2}$ Institute of Physiology, Academy of Sciences of the Czech Republic, Prague, Czech Republic, \\ ${ }^{3}$ Institute of Endocrinology, Prague, Czech Republic
}

Received December 4, 2007

Accepted February 12, 2009

On-line February 27, 2009

\begin{abstract}
Summary
Our aim was to assess the reaction of TNFa, resistin, leptin and adiponectin to lipid infusion. Eight healthy subjects underwent a 24-hour lasting infusion of lipid emulsion. Plasma concentrations and expressions of selected cytokines in subcutaneous fat were measured. TNFa plasma concentration did not change during the first 4 hours of hypertriglyceridemia, but a significant increase after 24 hours was detected ( $p<0.001$ for $0 ; 30 ; 240 \mathrm{~min}$ vs. $24 \mathrm{~h}$ ). Plasma concentration of resistin significantly increased at $30 \mathrm{~min}$ of infusion and remained elevated $(p<0.01$ for $0 \mathrm{~min}$ vs. 30; $240 \mathrm{~min}$; $<<0.001$ for 0 min vs. 24 h). Plasma concentrations of leptin and adiponectin did not show any significant changes. Although the expression of resistin in the subcutaneous adipose tissue tended to increase, the change was not significant. Expressions of TNFa, leptin and adiponectin were unaffected. In conclusions, our results indicate that acutely induced hyperlipidemia could influence the secretion of TNF $\alpha$ and resistin.
\end{abstract}

\section{Key words}

Resistin • TNFa • Leptin • Adiponectin • Insulin resistance • NEFA

- Triglycerides • Lipotoxicity

\section{Corresponding author}

T. Pelikánová, Diabetes Center, Institute for Clinical and Experimental Medicine, Vídeňská 1958/9, 14021 Prague, Czech Republic. E-mail: terezie.pelikanova@medicon.cz; Fax: +420 261363183

\section{Introduction}

Hyperlipidemia of either dietary origin or caused by lipid infusion promotes insulin resistance (IR) in rodents and humans (Boden and Chen 1995, Griffin et al. 1999, Leung et al. 2004). Pathophysiological mechanisms underlying the association between the elevation of plasma non-esterified fatty acids (NEFA) and IR have not been fully determined - for the evidence of interplay between glucose and NEFA see review by Cahová et al. (2007). Some of the pathways that lead to IR might include following cytokines produced by adipose tissue: TNF $\alpha$, resistin, leptin and adiponectin.

$\mathrm{TNF} \alpha$ is a promising candidate for mediating IR, although most of it comes from other sources than adipose tissue (Fain et al. 2003, Gabriely et al. 2002). Plasma concentrations of TNF $\alpha$ are related to obesity and IR (Hotamisligil et al. 1993). TNFa knock-out mice are more insulin sensitive than controls and there is the evidence that TNF $\alpha$ may directly interfere with insulin signaling by inhibiting phosphorylation of the insulin receptor (Hotamisligil et al. 1994). It impairs human preadipocyte differentiation, in mature adipocytes it decreases the activity of markers of differentiation, (Petruschke and Hauner 1993) and increases their apoptosis (Prins et al. 1997). TNFa has been shown to mediate NEFA-induced IR in 3T3-L1 adipocytes in vitro (Nguyen et al. 2005)

Resistin was named for its putative role in mediating IR in obesity. In mice, it is a product of an adipocyte-specific gene whose expression is downregulated by rosiglitazone (Arner 2005). Serum levels of resistin were found to be elevated in rodent models of obesity and diabetes implicating a dysregulation of resistin in these disease states (Arner 2005). In humans, 
however, the role of resistin is unclear. The human homologue of resistin is only expressed at very low levels in adipose tissue and in circulating monocytes, and the reports on its function are controversial (Janke et al. 2002, Savage et al. 2001).

Leptin is a cytokine secreted mainly by adipose tissue, its circulating levels are in direct proportion to adipose tissue mass and nutritional status (Maffei et al. 1995). Therefore, it is a likely candidate for mediating insulin sensitivity. It influences the human energy balance by altering energy intake and expenditure (Hukshorn and Saris 2004). It was shown in experimental animals that leptin infusion could prevent IR induced by acute lipid infusion (Dube et al. 2007).

Consistent inverse association between adiponectin and IR as well as the pro-inflammatory state has been established (Nedvídková et al. 2005). Several mechanisms of its metabolic effects have been described (Kadowaki et al. 2006, Whitehead et al. 2006): induction of glucose uptake and NEFA oxidation in muscle, increased insulin sensitivity and NEFA oxidation and reduced glucose output and NEFA influx in liver.

Our aim was to assess the reaction of $\mathrm{TNF} \alpha$, resistin, leptin and adiponectin to lipid infusion. We have evaulated both the plasma concentrations and expression of their genes in the abdominal subcutaneous adipose tissue in healthy humans.

\section{Subjects and methods}

\section{Subjects}

We examined eight young healthy males. All of them were euthyroid and none had a concomitant disease. They were not taking any drugs, and none had a family history of diabetes. Clinical characteristics are in Table 1. The study was conducted after approval by local ethics committee. Informed consent was obtained from all the individuals after the purpose, nature, and potential risks of the study had been explained.

\section{Experimental protocol}

The subjects were instructed to adhere to their ordinary lifestyle, to avoid changes in food intake, alcohol consumption, and vigorous exercise on the day before examination. They were examined after overnight fasting with only tap water allowed ad libitum. The study always started between 7:45-8:00 AM. Subjects were excluded from the study if the weight change was more than $3 \mathrm{~kg}$ in 6 months.
Table 1. Characteristics of the study group.

\begin{tabular}{|c|c|}
\hline$n$ & 8 \\
\hline Age (years) & $25.8 \pm 3.7$ \\
\hline Weight $(\mathrm{kg})$ & $83.4 \pm 4.7$ \\
\hline Body mass index $\left(\mathrm{kg} \cdot \mathrm{m}^{-2}\right)$ & $25 \pm 1.7$ \\
\hline Waist circumference (cm) & $88.5 \pm 5.0$ \\
\hline Fasting blood glucose (mmol.l $\left.I^{-1}\right)$ & $4.35 \pm 0.7$ \\
\hline Blood glucose at $120 \mathrm{~min}$ of OGTT $\left(\mathrm{mmol} . \mathrm{l}^{-1}\right)$ & $4.55 \pm 0.7$ \\
\hline Fasting IRI $\left(m I U . l^{-1}\right)$ & $4.50 \pm 2.85$ \\
\hline HbAlc (\%) - according to IFCC & $2.58 \pm 0.61$ \\
\hline Albuminuria $\left(\mu g . \mathrm{min}^{-1}\right)$ & $2.52 \pm 2.6$ \\
\hline Serum creatinine $\left(\mu \mathrm{mol} . I^{-1}\right)$ & $87 \pm 10.5$ \\
\hline Total cholesterol $\left(\mathrm{mmol}^{-1} \mathrm{l}^{-1}\right)$ & $4.24 \pm 0.73$ \\
\hline Triglycerides $\left(\right.$ mmol. $\left.l^{-1}\right)$ & $0.87 \pm 0.30$ \\
\hline HDL-cholesterol $\left(\right.$ mmol. $\left.l^{-1}\right)$ & $1.45 \pm 0.34$ \\
\hline LDL-cholesterol $\left(\right.$ mmol. $\left.l^{-1}\right)$ & $2.48 \pm 0.55$ \\
\hline
\end{tabular}

Data are expressed as mean \pm SD (IFCC, International Federation of Clinical Chemistry and Laboratory Medicine).

A 24-h infusion of lipid emulsion (Intralipid $20 \%$; Fresenius Kabi AB, Uppsala, Sweden) was administered through teflon cannula in the antecubital vein. Intralipid $20 \%$ contained soya oil $200 \mathrm{~g}$, egg lecithin $12 \mathrm{~g}$ and glycerol $22 \mathrm{~g}$ per 1 liter. The speed was set to $125 \mathrm{ml} . \mathrm{h}^{-1}$ for the first $4 \mathrm{~h}$, and then until the $24^{\text {th }}$ hour to a constant rate that was calculated to achieve a total dose of $3 \mathrm{~g}$ of fat.kg body weight ${ }^{-1} \cdot \mathrm{d}^{-1}$ This two-step setting of infusion was used to achieve both maximum effect and to stay within the clinically allowed boundaries. Thirty minutes before blood sampling a second cannula was inserted retrogradely into a wrist vein for blood collection. To assess the plasma levels of selected adipokines, blood samples were taken at $0 \mathrm{~min}$, $30 \mathrm{~min}, 240 \mathrm{~min}$ and $24 \mathrm{~h}$ of the infusion. Thirty minutes before taking each sample the hand was placed in a heated $\left(65^{\circ} \mathrm{C}\right)$ box in order to achieve venous blood arterialization. Needle biopsy of abdominal subcutaneous adipose tissue was performed before $(0 \mathrm{~min})$, and at the $4^{\text {th }}$ and $24^{\text {th }}$ hour of the lipid infusion. Under local anesthesia ( $1 \%$ trimecain in a field block pattern) an incision (3-4 mm) was made through the skin at the lower abdomen and a subcutaneous fat specimen (200 mg) was obtained by needle (Braunüle MT, no.4; B. Braun, Melsungen, Germany) aspiration. Different place and incision was used each time, but the same depth in the adipose tissue mass when performing the needle aspiration was attempted. The samples were washed in 
$\mathrm{NaCl} 0.9 \%$ solution, immediately frozen by liquid nitrogen and stored at $-80{ }^{\circ} \mathrm{C}$ until used for RNA extraction.

\section{Analytical procedures}

\section{Infusion monitoring}

Plasma glucose concentrations were measured on a Beckman analyzer (Beckman Instruments Inc, Fullerton, CA, USA) using the glucose oxidase method. Hemoglobin Alc was measured by fully automated analyzer Tosoh HLC-723 G7 (Tosoh Corporation, Tokyo, Japan). Method was calibrated to IFCC reference procedure (Mosca et al. 2007). Immunoreactive insulin (IRI) was determined by radioimmunoassay (Insulin IRMA kit, IMMUNOTECH as, Prague, Czech Republic). Plasma concentrations of NEFA were estimated by Free fatty acids, Half-micro test (Roche Diagnostics GmbH, Penzberg, Germany), whereas plasma concentrations of triglycerides (TG) by enzymatic assay (BIO-LA-TEST, PLIVA-Lachema, Brno, Czech Republic).

\section{Adipokine assessment in plasma}

Plasma concentrations of TNF $\alpha$ were measured by immunoassay (Human TNF- $\alpha$ UltraSensitive; BioSource Int., Camarillo, CA, USA) and the detection limit was $<0.09 \mathrm{pg} / \mathrm{ml}$, intra-assay and inter-assay coefficients of variation $(\mathrm{CV})$ of 5.3 to $6.7 \%$ and 8.2 to $9.7 \%$, respectively). Plasma concentrations of resistin were determined using a Human Resistin ELISA kit (BioVendor Lab. Med. Inc., Brno, Czech Republic) the detection limit was $0.033 \mathrm{ng} / \mathrm{ml}$, intra-assay and inter-assay $\mathrm{CV}$ of 2.8 to $3.4 \%$ and 5.1 to $6.9 \%$, respectively. Pplasma concentrations of leptin were measured by a Human Leptin ELISA kit (BioVendor Lab. Med. Inc., Brno, Czech Republic), the detection limit was $0.5 \mathrm{ng} / \mathrm{ml}$, intra-assay and inter-assay $\mathrm{CV}$ of 3 to $7.5 \%$ and 3.2 to $9.2 \%$, respectively. Plasma concentrations of adiponectin were determined using a Human Adiponectin ELISA kit (BioVendor Lab. Med. Inc., Brno, Czech Republic) the detection limit was $210 \mathrm{ng} / \mathrm{ml}$, intra-assay and inter-assay $\mathrm{CV}$ of 6.4 to $7 \%$ and 7.3 to $8.2 \%$, respectively (all according to manufacturers instructions).

\section{Assessment of expressions in adipose tissue}

Expression of each adipokine was analyzed by the real-time PCR method. Subcutaneous adipose tissue (100 mg) was excised from the biopsy, and homogenized in $1 \mathrm{ml}$ of a QIAzol Lysis Reagent (Guanidin Thiocyanate
- Phenol solution) for $2 \mathrm{~min}$. The RNA was isolated from the liquid nitrogen frozen biopsy using the RNeasy Lipid Tissue Mini Kit (QIAGEN, Valencia, CA, USA) and QIAzol Lysis Reagent (QIAGEN, Valencia, CA, USA). Possible contamination of RNA with genomic DNA remains was taken off by DNase digestion (RNase-free DNase Set; QIAGEN, Valencia, CA, USA). The cDNA was synthesized using a recombinant Omniscript Reverse Transcriptase (QIAGEN, Valencia, CA, USA), Ribonuclease Inhibitor from human placenta (SIGMA, St. Louis, MO, USA), and (dT) $)_{16}$ oligonucleotides.

The real-time PCR procedure itself has been carried out on the DNA Engine Opticon 2 System (MJ Research, Waltham, MA, USA). HotStar Taq DNA polymerase and SYBR Green fluorescent dye (QuantiTec SYBR Green PCR Kit, QIAGEN, Valencia, CA, USA) were used for the RT-PCR reaction. To eliminate the influence of primer dimmers, negative controls were used. The human gene cyclophilin was used as a reference. Primers used are shown in Table 2. The data were processed by Q-gene 96 software.

\section{Statistical analysis}

The time profile was evaluated using a repeated measures ANOVA model consisting of the time and subject factors. To evaluate the differences between basal values and individual stages of the time profile, the ANOVA testing was followed by least significant difference multiple comparisons. A probability level of $\mathrm{p}<0.05$ was considered as statistically significant in all statistical tests. Due to non-Gaussian data distribution in most of the dependent variables, these data underwent a power transformation to attain distributional symmetry and constant variance. Non-homogeneities were detected using residual diagnostics. The experimental points showing absolute values of studentized residuals greater than 3 were excluded from the analysis. With the exception of serum leptin levels $(6.3 \%)$, the proportions of such data never exceed $5 \%$ of the total number. Statistical software Statgraphics Plus v. 5.1 from Manugistics (Rockville, MD, USA) was used for calculations.

\section{Results}

Our primary goal was to assess the reaction of selected adipokines to acute lipid infusion and the following results were obtained. TNF $\alpha$ plasma concentration did not change during the first $4 \mathrm{~h}$ of hypertriglyceridaemia, but a significant increase after $24 \mathrm{~h}$ 
Table 2. Primers used for RT-PCR of the subcutaneous adipose tissue samples taken during the lipid infusion.

\begin{tabular}{|c|c|c|c|}
\hline Gene & $\begin{array}{l}\text { accession } \\
\text { number }\end{array}$ & forward primer & reverse primer \\
\hline Adiponectin & XM_290602 & $\begin{array}{l}\text { HACRP30-F: } \\
\text { 5'-GGT TCA ATG GCT TGT TTG C -3' }\end{array}$ & $\begin{array}{l}\text { HACRP30-R: } \\
\text { 5'-TCA TCC CAA GCT GAT TCT G-3' }\end{array}$ \\
\hline Leptin & NM_000230 & $\begin{array}{l}\text { Hleptin-F: } \\
\text { 5'-CCC TAA GCC TCC TTT TGC T-3' }\end{array}$ & $\begin{array}{l}\text { Hleptin-R: } \\
\text { 5'-GCT AAG AGG GGA CAA GAC A-3' }\end{array}$ \\
\hline$T N F \alpha$ & $\begin{array}{l}\text { X02910 } \\
\text { X02159 }\end{array}$ & $\begin{array}{l}\text { HTNFa-F: } \\
\text { 5'-CTA TCT GGG AGG GGT CTT C-3' }\end{array}$ & $\begin{array}{l}\text { HTNFa-R: } \\
\text { 5'-TTG GGA AGG TTG GAT GTT C -3' }\end{array}$ \\
\hline Resistin & AY207314 & $\begin{array}{l}\text { HRETN-F: } \\
\text { 5'-ATA AGC AGC ATT GGC CTG G-3' }\end{array}$ & $\begin{array}{l}\text { HRETN-R: } \\
\text { 5'-TGG CAG TGA CAT GTG GTC T-3' }\end{array}$ \\
\hline Cyclophilin & XM_090070 & $\begin{array}{l}\text { HCLPNa-F: } \\
\text { 5'-CAA ATG CTG GAC CCA ACA CA -3' }\end{array}$ & $\begin{array}{l}\text { HCLPNa-R: } \\
\text { 5'-TGC CAT CCA ACC ACT CAG TC-3' }\end{array}$ \\
\hline
\end{tabular}
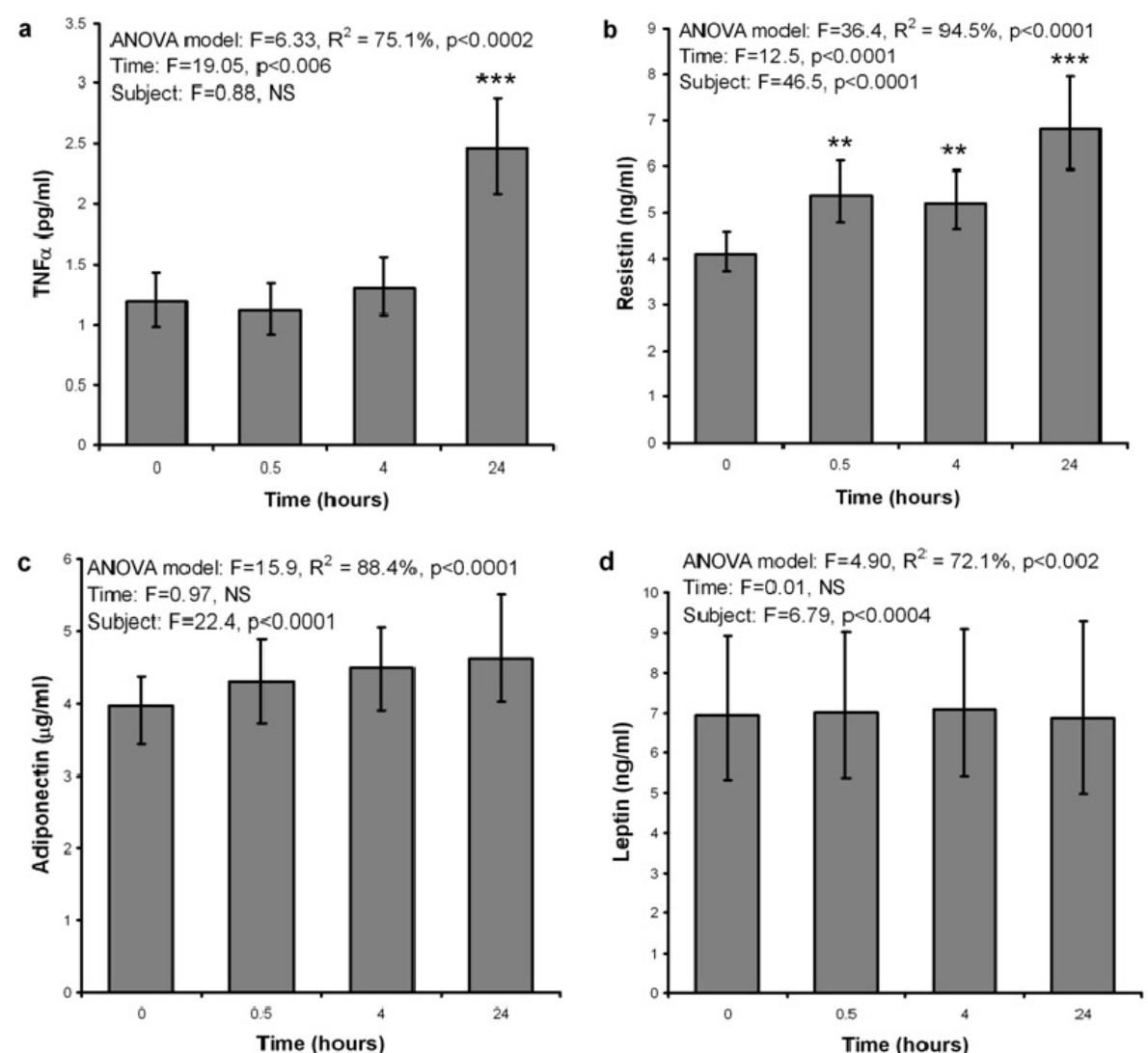

Fig. 1a-d. Plasma levels of selected adipokines during 24-hour lipid infusion. The bars with error bars represent re-transformed means with their $95 \%$ confidence intervals. $F$ in the embedded tables represents Fisher's statistics for individual factors. $R^{2}$ (squared correlation coefficient of the linear model) symbolize the proportion of the total variability in the dependent variable, which is explained by the ANOVA model. Asterisks symbolize significant differences between individual stages of the time profiles and basal values (** for $\mathrm{p}<0.01, * * *$ for $\mathrm{p}<0.001$ ) as detected by least significant difference multiple comparisons.

was detected ( $\mathrm{p}<0.001$ for $0 ; 30 ; 240$ min vs. 24 h; Fig. 1a). The expression of TNF $\alpha$ in subcutaneous adipose tissue did not change (Fig. 2a). Plasma concentration of resistin significantly increased at $30 \mathrm{~min}$ of infusion and remained elevated throughout the $24 \mathrm{~h}$ ( $\mathrm{p}<0.01$ for 0 min vs. 30; 240 min; $\mathrm{p}<0.001$ for 0 min vs. 24 h; Fig. 1b). The expression of resistin in the subcutaneous adipose tissue tended to increase, but the change was not significant (Fig. 2b). Plasma concentrations of leptin and adiponectin (Fig. 1c-d) did not show any significant changes and their expressions were not significantly altered.

To validate the effectiveness of lipid infusion, 

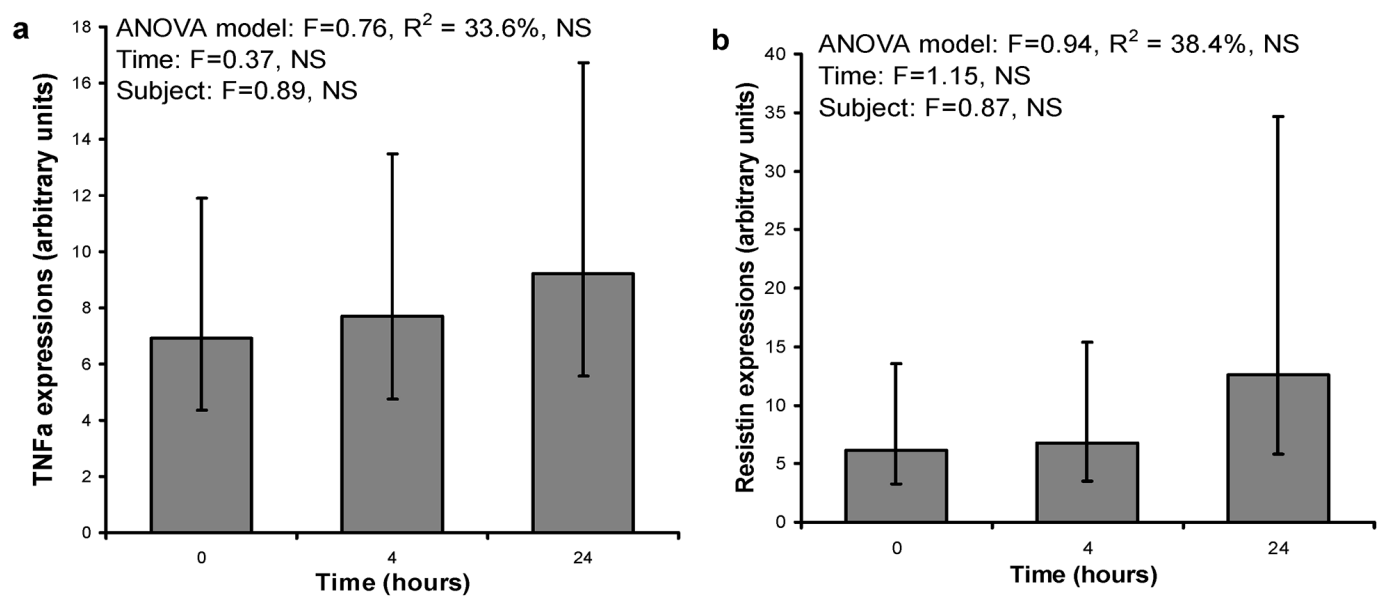

Fig. 2a,b. Expressions of selected adipokines in subcutaneous abdominal adipose tissue during 24-hour lipid infusion. The bars with error bars represent re-transformed means with their $95 \%$ confidence intervals (expression of selected cytokine related to expression of cyclophilin). The changes in time were assessed by ANOVA and are not statistically significant.
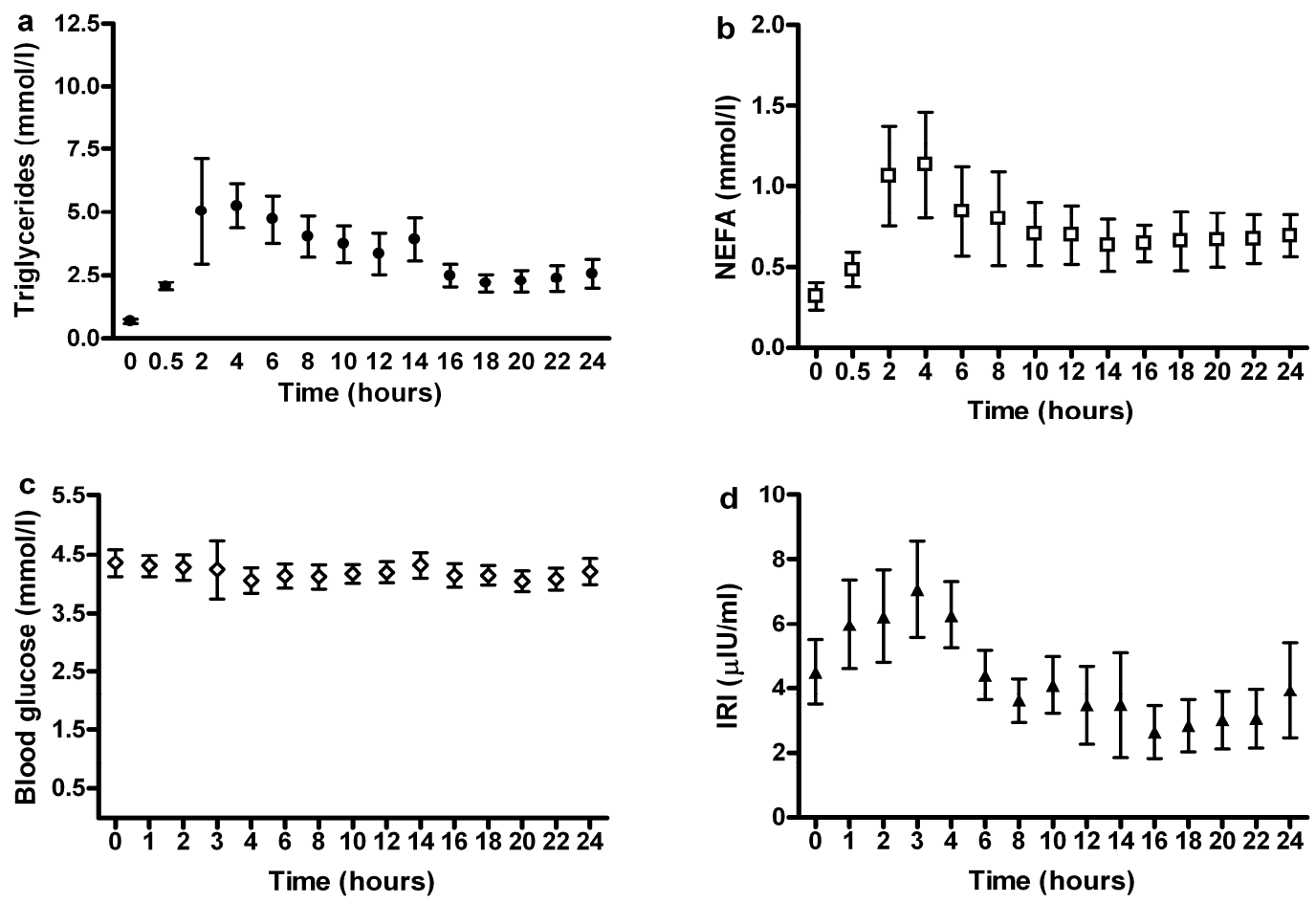

Fig. 3a-d. Concentrations of serum triglycerides $(\bullet)$, non-esterified free fatty acids (NEFA, $\square$ ), blood glucose $(\diamond)$ and immunoreactive insulin (IRI, $\mathbf{\Lambda}$ ) during the 24-hour lipid infusion. Data are shown as means with their $95 \%$ confidence intervals.

plasma levels of TG, NEFA, glucose and IRI were monitored. TG increased almost 8-fold and NEFA about 3.5 -fold in the $4^{\text {th }}$ hour and they remained elevated until the end of infusion at more than 3 -fold and 2-fold, respectively (Figs $3 \mathrm{a}$ and $3 \mathrm{~b}$ ). Blood glucose was stable throughout the $24 \mathrm{~h}$ (Fig. 3c). After initial modest rise, IRI concentrations were also stable (Fig. 3d). Cytokine plasma concentrations did not correlate with IRI concentrations (data not shown).

\section{Discussion}

We have characterized the plasma levels of adipose tissue cytokines and their expression in adipose tissue during pharmacologically-induced hyperlipidemia. This was achieved by an intravenous lipid infusion, in which the effectiveness in rise of plasma TG and NEFA was verified. We have decided not to use heparin infusion alongside because heparin as a co-factor of a lipoprotein lipase would decrease plasma TG concentrations and 
increase plasma NEFA concentrations, which was not our aim. It could also add further bias through possible unknown effects. Since heparin was used in some further cited experiments (Garcia-Lorda et al. 2003, Nisoli et al. 2000, Yang et al. 2005), this sole fact could be the reason for differences in results obtained.

Our finding of an increase in $\mathrm{TNF} \alpha$ plasma concentration during lipid infusion is novel. It is partly in accordance with the report of Nisoli et al. (2000) who found the increase in TNF $\alpha$ gene expression in subcutaneous gluteal fat tissue after a 5-h intralipid/ heparin infusion. In our results, the expressions in adipose tissue showed only a tendency to increase but not a significant rise. This can be explained by the differences in expressions in different fat depots. Both in human (Fain et al. 2003) and rodent (Gabriely et al. 2002) studies, it has been reported that production of both of resistin and TNF $\alpha$ is much higher in visceral than in subcutaneous fat. Moreover, most of the free circulating TNF $\alpha$ comes from circulating monocytes and significant amounts of resistin, although originally reported as adipocyte-specific (Kim et al. 2001), might be of the same source (Savage et al. 2001).

During lipid infusion, plasma concentrations of resistin have increased significantly. This is in accordance with the reports from animal models (Yang et al. 2005) where intralipid/heparin infusion induced hepatic and peripheral IR and was associated with elevated plasma resistin levels. In human, it is a novel observation. Since the increase in expression of resistin mRNA in subcutaneous adipose tissue was not significant, we can conclude that this adipocyte depot is not responsible for its increased plasma concentration.

Plasma concentration of leptin did not show any significant changes and its expression was not significantly altered. Although most studies have not shown direct effect of lipid infusion on leptin, as when consistent release from adipose tissue during lipid without heparin infusion was reported (Samra et al. 1998), some other results were also obtained: no change in plasma levels together with increase in leptin RNA expression in adipocytes in gluteal region during lipid and heparin infusion (Nisoli et al. 2000) and modest decline of its plasma levels during lipid and heparin infusion (Garcia-Lorda et al. 2003).

Response of adiponectin to acute lipid load was also not statistically significant. The same result of unchanged plasma concentrations was observed during intralipid/heparin infusion (Krzyzanowska et al. 2007).
Lipid infusion resulting in a subsequent increase in NEFA plasma concentrations is a well-known method used for inducing IR (Boden and Chen 1995, Griffin et al. 1999, Leung et al. 2004). Therefore, although we have not measured insulin sensitivity, we suggest that the changes we have observed might be implicated in the pathogenesis of lipid-induced IR. Our results are in agreement with a theory that $\mathrm{TNF} \alpha$ is implicated in NEFA-induced IR as shown in vitro (Nguyen et al. 2005). For resistin it is an unclear result because it is often found not to be associated with IR (Utzschneider et al. 2005), although the studies are usually limited to correlations between resistin and various measures of metabolic syndrome. Rather exception is a report of Sheng et al. (2008) where overexpression of resistin in human hepatocytes induced IR most likely by blocking insulin signal transduction pathways of PI-3K/Akt and of $\mathrm{CAP} / \mathrm{c}-\mathrm{cbl}$.

We are aware that there are limits to our study. Increase in plasma lipid concentrations by intravenous infusion certainly differs from dietary and lifestyle induced hyperlipidemia observed in real life. Small number of subjects examined might have prevented us from seeing some other possibly significant results and therefore the value of "negative" results is limited. In addition, the lack of placebo control, which was not done due to the potential troublesome interpretation of a $24-\mathrm{h}$ long fasting, to some extent limits the reliability of "positive" results. Circadian variations were partly assessed by 24-h duration. Glycerol (a component of intralipid emulsion) fortunately does not affect insulin secretion (Boden and Chen 1999, Pelkonen et al. 1968), glucose effectiveness (Hawkins et al. 2003) or insulin sensitivity (Ferrannini et al. 1983). However, the effect of glycerol on resistin and TNF $\alpha$ can not be excluded. Resistin could also be affected by hyperinsulinemia, although this observation was made at several-fold higher insulin concentrations (Krušinová et al. 2007) than observed during our lipid infusion. We have also found significant inter-individual and intra-individual differences of the mRNA content in adipose tissue samples for each adipokine. We must, however, note that this could partly be due to different adipocytes/stromavascular cells ratio in each sample. In future studies, this can be assessed by separation of these fractions by collagenase tissue digestion (Rodbell 1963).

In conclusion, our results indicate that acutely induced hyperlipidemia could increase the secretion of TNF $\alpha$ and resistin. This finding supports the hypothesis 
that these adipokines could be involved in the pathogenesis of lipid-induced IR.

\section{Conflict of Interest}

There is no conflict of interest.

\section{Acknowledgements}

The skilful technical assistance of Ms. Dana Lapešová and Ms. Dagmar Šišáková is gratefully acknowledged. Supported by grant from the Health Ministry of the Czech Republic (projects No. IGA CZ NR 9359-3).

\section{References}

ARNER P: Resistin: yet another adipokine tells us that men are not mice. Diabetologia 48: 2203-2205, 2005.

BODEN G, CHEN X: Effects of fat on glucose uptake and utilization in patients with non-insulin-dependent diabetes. $J$ Clin Invest 96: 1261-1268, 1995.

BODEN G, CHEN X: Effects of fatty acids and ketone bodies on basal insulin secretion in type 2 diabetes. Diabetes 48 : 577-583, 1999.

CAHOVÁ M, VAVŘíNKOVÁ H, KAZDOVÁ L: Glucose-fatty acid interaction in skeletal muscle and adipose tissue in insulin resistance. Physiol Res 56: 1-15, 2007.

DUBE JJ, BHATT BA, DEDOUSIS N, BONEN A, O'DOHERTY RM: Leptin, skeletal muscle lipids, and lipidinduced insulin resistance. Am J Physiol 293: R642-R650, 2007.

FAIN JN, CHEEMA PS, BAHOUTH SW, LLOYD HILER M: Resistin release by human adipose tissue explants in primary culture. Biochem Biophys Res Commun 300: 674-678, 2003.

FERRANNINI E, BARRETT EJ, BEVILACQUA S, DEFRONZO RA: Effect of fatty acids on glucose production and utilization in man. J Clin Invest 72: 1737-1747, 1983.

GABRIELY I, MA XH, YANG XM, ATZMON G, RAJALA MW, BERG AH, SCHERER P, ROSSETTI L, BARZILAI N: Removal of visceral fat prevents insulin resistance and glucose intolerance of aging: an adipokine-mediated process? Diabetes 51: 2951-2958, 2002.

GARCIA-LORDA P, NASH W, ROCHE A, PI-SUNYER FX, LAFERRERE B: Intralipid/heparin infusion suppresses serum leptin in humans. Eur J Endocrinol 148: 669-676, 2003.

GRIFFIN ME, MARCUCCI MJ, CLINE GW, BELL K, BARUCCI N, LEE D, GOODYEAR LJ, KRAEGEN EW, WHITE MF, SHULMAN GI: Free fatty acid-induced insulin resistance is associated with activation of protein kinase $C$ theta and alterations in the insulin signaling cascade. Diabetes 48: 1270-1274, 1999.

HAWKINS M, TONELLI J, KISHORE P, STEIN D, RAGUCCI E, GITIG A, REDDY K: Contribution of elevated free fatty acid levels to the lack of glucose effectiveness in type 2 diabetes. Diabetes 52: 2748-2758, 2003.

HOTAMISLIGIL GS, SHARGILL NS, SPIEGELMAN BM: Adipose expression of tumor necrosis factor-alpha: direct role in obesity-linked insulin resistance. Science 259: 87-91, 1993.

HOTAMISLIGIL GS, BUDAVARI A, MURRAY D, SPIEGELMAN BM: Reduced tyrosine kinase activity of the insulin receptor in obesity-diabetes. Central role of tumor necrosis factor-alpha. J Clin Invest 94: 1543-1549, 1994.

HUKSHORN CJ, SARIS WH: Leptin and energy expenditure. Curr Opin Clin Nutr Metab Care 7: 629-633, 2004.

JANKE J, ENGELI S, GORZELNIAK K, LUFT FC, SHARMA AM: Resistin gene expression in human adipocytes is not related to insulin resistance. Obes Res 10: 1-5, 2002.

KADOWAKI T, YAMAUCHI T, KUBOTA N, HARA K, UEKI K, TOBE K: Adiponectin and adiponectin receptors in insulin resistance, diabetes, and the metabolic syndrome. J Clin Invest 116: 1784-1792, 2006.

KERN PA, SAGHIZADEH M, ONG JM, BOSCH RJ, DEEM R, SIMSOLO RB: The expression of tumor necrosis factor in human adipose tissue. Regulation by obesity, weight loss, and relationship to lipoprotein lipase. J Clin Invest 95: 2111-2119, 1995.

KIM KH, LEE K, MOON YS, SUL HS: A cysteine-rich adipose tissue-specific secretory factor inhibits adipocyte differentiation. J Biol Chem 276: 11252-11256, 2001.

KRUŠINOVÁ E, KLEMENTOVÁ M, KOPECKÝ J, WOHL P, KAZDOVÁ L, MLEJNEK P, PRAVENEC M, HILL M, PELIKÁNOVÁ T: Effect of acute hyperinsulinaemia with and without angiotensin II type 1 receptor blockade on resistin and adiponectin concentrations and expressions in healthy subjects. Eur J Endocrinol 157: 443-449, 2007. 
KRZYZANOWSKA K, MITTERMAYER F, KRUGLUGER W, RODEN M, SCHERNTHANER G, WOLZT M: Adiponectin concentrations increase during acute FFA elevation in humans treated with rosiglitazone. Horm Metab Res 39: 769-772, 2007.

LEUNG N, SAKAUE T, CARPENTIER A, UFFELMAN K, GIACCA A, LEWIS GF: Prolonged increase of plasma non-esterified fatty acids fully abolishes the stimulatory effect of 24 hours of moderate hyperglycaemia on insulin sensitivity and pancreatic beta-cell function in obese men. Diabetologia 47: 204-213, 2004.

MAFFEI M, HALAAS J, RAVUSSIN E, PRATLEY RE, LEE GH, ZHANG Y, FEI H, KIM S, LALLONE R, RANGANATHAN S, et al.: Leptin levels in human and rodent: measurement of plasma leptin and ob RNA in obese and weight-reduced subjects. Nat Med 1: 1155-1161, 1995.

MOSCA A, GOODALL I, HOSHINO T, JEPPSSON JO, JOHN WG, LITTLE RR, MIEDEMA K, MYERS GL, REINAUER H, SACKS DB, WEYKAMP CW: Global standardization of glycated hemoglobin measurement: the position of the IFCC Working Group. Clin Chem Lab Med 45: 1077-1080, 2007.

NEDVÍDKOVÁ J, SMITKA K, KOPSKÝ V, HAINER V: Adiponectin, an adipocyte-derived protein. Physiol Res 54: 133-140, 2005.

NGUYEN MT, SATOH H, FAVELYUKIS S, BABENDURE JL, IMAMURA T, SBODIO JI, ZALEVSKY J, DAHIYAT BI, CHI NW, OLEFSKY JM: JNK and tumor necrosis factor-alpha mediate free fatty acid-induced insulin resistance in 3T3-L1 adipocytes. $J$ Biol Chem 280: 35361-35371, 2005.

NISOLI E, CARRUBA MO, TONELLO C, MACOR C, FEDERSPIL G, VETTOR R: Induction of fatty acid translocase/CD36, peroxisome proliferator-activated receptor-gamma2, leptin, uncoupling proteins 2 and 3 , and tumor necrosis factor-alpha gene expression in human subcutaneous fat by lipid infusion. Diabetes 49 : 319-324, 2000.

PELKONEN R, MIETTINEN TA, TASKINEN MR, NIKKILA EA: Effect of acute elevation of plasma glycerol, triglyceride and FFA levels on glucose utilization and plasma insulin. Diabetes 17: 76-82, 1968.

PETRUSCHKE T, HAUNER H: Tumor necrosis factor-alpha prevents the differentiation of human adipocyte precursor cells and causes delipidation of newly developed fat cells. J Clin Endocrinol Metab 76: 742-747, 1993.

PRINS JB, NIESLER CU, WINTERFORD CM, BRIGHT NA, SIDDLE K, O'RAHILLY S, WALKER NI, CAMERON DP: Tumor necrosis factor-alpha induces apoptosis of human adipose cells. Diabetes 46: 19391944, 1997.

RODBELL M: Metabolism of isolated fat cells. J Biol Chem 239: 375-380, 1963.

SAMRA JS, GILES SL, SUMMERS LK, EVANS RD, ARNER P, HUMPHREYS SM, CLARK ML, FRAYN KN: Peripheral fat metabolism during infusion of an exogenous triacylglycerol emulsion. Int J Obes Relat Metab Disord 22: 806-812, 1998.

SAVAGE DB, SEWTER CP, KLENK ES, SEGAL DG, VIDAL-PUIG A, CONSIDINE RV, O'RAHILLY S: Resistin/ Fizz3 expression in relation to obesity and peroxisome proliferator-activated receptor-gamma action in humans. Diabetes 50: 2199-2202, 2001.

SHENG CH, DI J, JIN Y, ZHANG YC, WU M, SUN Y, ZHANG GZ: Resistin is expressed in human hepatocytes and induces insulin resistance. Endocrine 33: 135-143, 2008.

UTZSCHNEIDER KM, CARR DB, TONG J, WALLACE TM, HULL RL, ZRAIKA S, XIAO Q, MISTRY JS, RETZLAFF BM, KNOPP RH, KAHN SE: Resistin is not associated with insulin sensitivity or the metabolic syndrome in humans. Diabetologia 48: 2330-2333, 2005.

WHITEHEAD JP, RICHARDS AA, HICKMAN IJ, MACDONALD GA, PRINS JB: Adiponectin - a key adipokine in the metabolic syndrome. Diabetes Obes Metab 8: 264-280, 2006.

YANG G, LI L, FANG C, ZHANG L, LI Q, TANG Y, BODEN G: Effects of free fatty acids on plasma resistin and insulin resistance in awake rats. Metabolism 54: 1142-1146, 2005. 